\title{
Scotland and England's colliding nationalisms: neoliberalism and the fracturing of the United Kingdom
}

\author{
John Bone ${ }^{1}$ \\ Accepted: 8 September 2021 \\ (c) The Author(s), under exclusive licence to Springer Nature Limited 2021
}

\begin{abstract}
This paper explores the growing divide between Scotland and England, a schism that was beginning to take form with Scottish devolution and which has grown exponentially since the Independence Referendum of 2014. The central argument presented in the paper is that renewed impetus for national distinction and self-determination in Scotland is best understood as one facet of a much wider popular disenchantment and growing restiveness with the trajectory of contemporary UK politics, culture and society that has found an outlet via a resurgent nationalist discourse and institutional framework. Analysis here is approached via the application of an original biosocial theory with the aim of presenting further insights into the underlying processes driving contemporary political instability. Moreover, it is argued that this scenario can be understood, and may shed light upon, the wider rise in nationalist and populist sentiment that is contributing to increasing political turbulence across Europe and beyond.
\end{abstract}

Keywords Nationalism $\cdot$ Scottish independence $\cdot$ Brexit $\cdot$ Neoliberalism $\cdot$ Populism $\cdot$ Biosocial theory

\section{Introduction}

..."What constitutes a nation?" In the final analysis the coincidence of the customary tangible attributes of nationality, such as common language and religion, are not determinative. The prime requisite is subjective and consists of the self-identification of people with a group - with its past, its present, and, what is most important, its destiny (Connor 1994, p. 4).

From the Scottish Independence Referendum, through the EU referendum of 2016 to the outcome of the General Election of 2019, the political polarization of the two

John Bone

j.bone@abdn.ac.uk

1 University of Aberdeen, Aberdeen AB24 3QY, Scotland, UK 
largest nations of the UK appears to have become increasingly intractable, a scenario further underlined by the Scottish Parliament and English council elections of 2021. This fracturing of the union appears consistent with a trend towards a generally more febrile and unstable political scene that has been experienced across many developed and developing democracies, emerging at least since the turn of the century. While current instabilities, as argued below, appear intrinsically bound up with an interweaving of socio-economic and cultural concerns, a significant aspect of this growing unease has crystallised via resurgent nationalist sentiments and movements (Edgerton 2019; Cox 2021).

As the central argument of this paper contends, in some senses recourse to nationalist impulses can be viewed as a familiar development, particularly in anxious and atomised societies where vehicles for communal action and collective affiliation are thin on the ground, as nationalism operates as a default source of cultural defence, community and solidarity, binding together often amorphous coalitions disaffected by the status quo but, arguably, from often quite contradictory perspectives (Cox 2021). Support for Brexit, for example, has been associated with those who feel politically, culturally and economically disenfranchised, the so-called 'left behind' of post-industrial England (and Wales), presumed to regard the EU as an 'alien' political establishment that failed to reflect their values and interests or address their insecurities (Eatwell and Goodwin 2018; Byrne et al 2020; Goodwin and Heath 2016; Gusterson 2017). Brexit, as we know, was also substantially supported by older middle and more comfortable working-class social conservatives with concerns around immigration and sovereignty (Goodwin and Heath 2016). Seemingly uniting these groups was a form of resurgent English national identity, broadly consistent with a rising tide of nationalism that has moved from the radical margins to the mainstream, while sharing significant features with the form of populist politics that arose in Trump's United States, and to some extent in Poland, Hungary, Turkey and a number of other nations where populism is in the ascendant (Baier 2016; Eatwell and Goodwin 2018). One caveat here is that Euroscepticism has also been driven by an elite pro-global grouping of free-market conservatives opposed to EU regulatory constraints on business and, while some of this group may also have harboured nationalist impulses, the motivation may have been more pecuniary than populist. Conversely, there was also a significant anti-Brexit vote amongst younger, well-educated cosmopolitans in England's major cities, and particularly London. Overall, as we know, however, the latter were substantially outnumbered by the nationalist, anti-immigration and anti-establishment pro-Brexit surge across England as a whole (Hobolt 2016).

The divide between the UK nations, with England and Wales voting Leave and Scotland and Northern Ireland decisively voting for Remain, was also seen to be bound up with rising nationalist sentiment and identity to a significant degree (Goodwin and Heath 2016). Setting aside the complexities of the Northern Ireland vote, which was bound up with its historically tortuous relationships with both the UK and its southern neighbour, the Welsh Leave vote has been attributed to English residents tipping the balance (Dorling 2019). Debate around the Brexit vote in Scotland, however, extended the sense of division that had emerged between Scotland and England with the 'Indyref', providing further indication that the nation's 
political path and identity seemed fundamentally oppositional, at least in terms of its espoused values, from the predominantly right wing forms of populist nationalism currently in vogue in England, the US and elsewhere (McGarvey and Stewart 2016; Paul 2020). Thus, Scotland's brand of nationalism has long presented itself as being more measured, open, positive and inclusive than its English variant, albeit sharing common tropes of collective destiny and community (McGarvey and Stewart 2016). However, as argued here, beneath its superficially rational and optimistic discourse the current strand of Scottish national reawakening may also share some further important commonalities with its seeming opposites, in terms of constituencies experiencing a sense of incoherence and lack of control over various aspects of their lives and their future. Thus, in unequal and insecure societies, simplifying discourses of revival, national community and 'control' appear to have had significant appeal, providing fertile ground for populist politicians while destabilising prior political norms (Eatwell and Goodwin 2018). As Fieldhouse et al. (2020) have observed, the divergent nationalist politics within the UK is consistent with a wider pattern of increasing electoral volatility that has intensified since 2017.

Clearly, the relationship between inequality, insecurity and political instability is a long recognised phenomenon that is prominent in many accounts of contemporary political and societal turbulence (Mishra 2017; Eatwell and Goodwin 2018). However, this paper asserts that the mechanisms by which this arises are often assumed and not clearly drawn, while new understandings as to how we relate to societal conditions warrant attention in terms of pointing towards some of the deeper processes underlying contemporary political engagement and action. From this perspective, the theoretical analysis offered below is informed by an original biosocial model, informed by concepts and emerging evidence from psychology, neuroscience and sociology, as a means of further illuminating how neoliberalism, as the dominant socio-economic discourse of the current era, and the insecurities and inequalities it has wrought, has driven the current wave of political instability, including cleavages within the UK (Bone 2016). Moreover, against this background, the historically destabilising COVID 19 pandemic, in terms of both its compounding social and economic impact and capacity to exacerbate other political tensions, appears to have deepened the growing schism between the UK's largest nations. This level of analysis, however, is firstly approached via a discussion of some of the more overt, political and cultural factors contributing to the growing divide between Scotland and England.

\section{A disunited nation}

There can be little controversy in suggesting that the highly charged debate prior to the Scottish Independence Referendum of 2014 appeared as the catalyst for an undercurrent of disaffection that has only grown since, seemingly exhuming and recharging the historically uneasy relationship between Scotland and England, while the bid for Scottish secession was lost it was by a dramatically tighter margin than anticipated, sending shock waves through the UK political establishment in the closing stages of the race. Moreover, with the landslide victory for the Scottish National 
Party (SNP) in the subsequent General Election, there was a sense that something had awoken in the pre-referendum months in Scotland that might not quickly subside, while its reverberations continue to be keenly felt in the politics of post-Brexit and COVID Britain.

It may be noted that, as many commentators at the time of the Scottish referendum observed, jingoistic tabloid headlines aside, debate preceding the poll did not appear to be strongly rooted in nationalistic fervour. Rather, nationalism in Scotland appeared less strident, with the impetus behind the 'Yes' campaign being widely assumed to be a poll undertaken as a regrettable but pragmatic step, aimed at releasing Scotland from the yoke of a succession of Westminster governments seen to have embedded Margaret Thatcher's neoliberal legacy. This included its 'Blairite' incarnation in a Labour Party whose acceptance of the key tenets of neoliberalism was at odds with the values of a broad swathe of the Scottish public (Davidson 2014; Byrne et al 2020). As Davidson asserted, the divide between the Scots and English in the current era is 'surely one of policy rather than identity; of the content of the 'anti-reforms' imposed by Thatcher, not the accent with which they were announced' (Davidson et al. 2010 p. v).

This broad line of argument holds that neoliberalism was never embraced in Scotland in anything like the manner with which it had been accepted by a significant portion of the English populace, albeit that Thatcherite neoliberalism had also been highly divisive south of the border (Gallas 2015; Paul 2020). In approaching this argument it is also recognised that neoliberalism of itself is a contested term, and while extensive debate as to its meaning is not a central aim of this piece, briefly it is understood here as being both an economic doctrine, advocating low taxation, privatisation, a small state, minimal welfare provision and low regulation on business, as well being a cultural phenomenon promoting self-reliance, autonomy and competitiveness (Harvey 2007). On this latter point, while neoliberalism is often advanced under the banner of upholding individual, freedom, autonomy and open, competitive markets, in practice it has been argued that it has taken the form of re-regulation, as business interests and neoliberal policymakers have refashioned economy and society in favour of capital while simultaneously constraining the power and resources accruing to labour and the poor (Wacquant 2009).

Returning to the issue of the SNP's success, while the party's popularity has been growing since the 1970s, its major breakthrough occurred with its supplanting of Labour as Scotland's social democratic and anti-neoliberal standard bearers in the aftermath of the 'Indyref', a position further advanced by Labour's joining with the Tories in the 'Better Together' coalition, and which has been consolidated despite the party's brief leftward tack under Jeremy Corbyn.

At the time of the 2014 referendum, the rise of the Scottish National Party (SNP) might have been simply understood as a response to fading hopes of any significant political change of direction at Westminster. Thus, as above, a vision of contemporary Scottish self-determination emerged that, indeed, appeared little to do with nationalism in its regular sense. However, as argued below, the roots of Scotland's secessionist impulses seem to defy any neat separation between socio-economic cleavages and nationalist allegiances (Paul 2020). As argued here, there is a question as to how far popular discontents, political or otherwise, can be neatly disaggregated 
from the collective identities around which they are mobilized. As Davidson (2008) observed, national consciousness can be readily invoked by antipathy towards policy effects and in this case, as is discussed in more detailed below, with processes set in motion by atomization and economic insecurity.

The explanation for Scotland's restiveness being unambiguously founded on political policy differences also seems at odds with some evidence, questioning the extent to which Scots actually differ from their English counterparts in terms of political priorities (Keating 2011). Thus, while there is a seemingly clear and growing divergence in terms of broad political sentiment there is, arguably, greater difficulty in readily discerning unambiguous criteria on which this is founded.

In light of the above, it can be argued that this may render the task of understanding the various influences on what has been happening between Scotland and England in recent decades difficult to disentangle. In other words, how far is this a relatively straightforward political dispute that has selectively drawn upon a diaphanous nationalist platform for what is effectively political tribalism? Alternatively, and by contrast, is there something more substantial that can be garnered from exploring the roots of political disenchantment in Scotland and its relation to national collective cultural 'psyche' and self-identity, as interwoven facets of this resurgent national mobilization?

\section{Contemporary Scotland: resurgent nation or political tribe}

Scotland's political parties are addressing an electorate whose sense of Scottish identity has become more entwined with support for Scottish independence, a link that has seemingly been galvanised by both the 2014 independence referendum and the outcome of the 2016 EU referendum (Scholes and Curtice 2020, p. 12).

If the current mobilizing of Scottish self-determination is in fact an amalgam of economic and identity factors, how is Scotland's contemporary sense of self understood, and how might this be related to the socio-economic issues identified above?

When approaching issues of national identification the very obvious point that, as with neoliberalism, nationhood as a conceptual schema remains a contested terrain must be borne in mind. As many commentators have observed there are few collectives that regard themselves as nations that would qualify in terms the more widely understood meaning of the term, as being relatively homogenous collectives with a shared history and culture (McCrone 1992; Connor 1994). Rather, it has been 'imagined' that nationhood follows from statehood, where collective identity is forged by political elites via the totems of the state itself, albeit that as in this case further issues can be seen to emerge where this process is considered in relation to multinational entities such as the UK (Anderson 1983; McCrone 2002).

It has been an integral part of the state that people are made into citizens, owing loyalty, and in turn coming to feel themselves to be 'nationals'. (McCrone 1992, p. 302). 
On the one hand the dissolution of British identity may be understood with reference to the eclipsing of a declining imperial UK nation state's purchase over the collective 'imagination' of its multinational subjects, in favour of more regional affiliations revived by incipient nationhood; a condition long applicable to Ireland and now, albeit less dramatically, to Scotland and to an extent Wales. Thus, the centuries of warfare and empire that provided the collective experiences, rituals and indeed 'others' against which Britons could collectively mobilize, actually and/or symbolically, have eroded over time. In recent times, this is particularly applicable to fading memories of wartime Britain and the organs of the UK state as well as the vibrant British popular culture that had created a sense of affinity in the post-war era (Colley 1992). It is against this background that it has also been argued that the emergence of the Scottish Government, and Scotland's more recent political domination by the SNP, has provided the platform for a process whereby a residual sense of Scottish national identity has been disinterred and refashioned to fit with an emerging vision of Scottish independent statehood where 'in Scotland social democracy was underpinned by a revived and repoliticised national identity' (Keating 2007: 9).

\section{Scottish national identity: egalitarianism and social democracy}

With respect to 'deeper' identity factors that may be bound up with Scotland's divergence from the UK, Paterson offers an understanding while simultaneously problematizing notions of Scottish national culture and identity, and its potential relationship to policy. He argues that Scottish national identity treads a precarious and, to some extent, contradictory line between historically founded patriotism and humanist universalism. Thus, Scottish national identity requires the accommodation of two contradictory impulses, adopting the emotionally driven 'otherness' required to assume a sense of national identity while simultaneously accommodating a universalist rationalism and moral stance of solidarity, inclusiveness and collectivism (Paterson 2014; McGarvey and Stewart 2016).

That foundation of all modern Scottish political culture places Scotland absolutely at the heart of humanity. Indeed (given the Scots' tendency to messianic self-belief) it imagines Scotland as leading humanity to a more enlightenment state of affairs (Paterson 2014, p. 3).

As Paterson observes, this cultural vein can be understood as being forged of a founding set of principles that inspired Scotland to develop the view of itself as being especially rational, moral, empathic, compassionate, collectively oriented and egalitarian. This implies that key features of Scottish national identity developed that were highly compatible, if not synonymous, with the values of an enlightened modernity, but which can also be seen to be bound up with, as identified below, residual romantic features of Scottish identity. Paterson further indicates that Scottish identity was accommodated to a degree within the context of a modern imperial British culture purported to be ostensibly rationally oriented, reforming and internationalist (Paterson 2014, p. 3) albeit that, as we know, the actions provoked were regularly darker and less enlightened (Elkins 2005). Such observations, however, provide a useful starting point for understanding 
the connections between Scotland's national identification and contemporary political culture.

The notion of Scots as being imbued with a distinctive sense of egalitarianism and collectivism was also advanced by McCrone, who characterized this in terms of a longstanding embracing of values that privileged equality of opportunity and meritocracy, but with a focus on the 'commonweal'. According to McCrone, these cultural tropes also have their origins in highly selective interpretations of Scotland's past and imaginings of an egalitarian Gaeldom and the 'Kailyard' imagery spawned by post-reformation Scottish Presbyterianism, as informing a 'Scottish Myth' of its people as ambitious, but democratic, empathic and socially orientated. McCrone also argued at the time that this aspect of Scottish self-identity was strengthened by greater integration with, and loss of control to, England (McCrone 1992; Paul 2020).

Essentially, the Scottish Myth is not dependent on 'facts', because it represents a set of social, self-evident values, a social ethos, a celebration of sacred beliefs about what it is to be Scottish. It helped to underpin a social order that placed a premium on collective, co-operative and egalitarian commitments. It is an ideological device for marking off the Scot from the English... It becomes the essence of Scotland (McCrone 1992, p. 120).

McCrone's argument has been revisited by Hassan (2012) and Paul (2020), who also point to the fact that the 'Scottish Myth' of collective solidarity and egalitarianism is just that, in that it often appears at odds with the evidence. Hassan's critique in particular focuses on the fact that Scotland has some of the highest levels of economic and health inequalities amongst developed nations, with the latter most significantly experienced in the post-industrial heartlands of West Central Scotland (Hassan 2012). However, as these writers also appear clearly aware, the veracity of the foundations on which identity forming narratives are founded appears much less important than how they are received, a theme central to both Anderson and Hobsbawn and Rangers' respective understanding of national building via imagined community and invented tradition (Anderson 1983; Hobsbawm and Ranger 1983). As with many collective identities, moreover, dissonances and conflicting evidence can be rationalized in a paradoxical manner that actually contributes to the strengthening of belief and/or identity. In this particular instance, the fact that 'egalitarian Scotland' is not particularly egalitarian can be readily attributed to the iniquities of Westminster and English rule subverting the 'true' aspirations of the Scottish people, particularly since the advent of Thatcherism, reinforcing Scotland's sense of its own moral superiority (McCrone 1992). The latter also plays to another key aspect of Scottish national identity, tartanry, which draws on images of a romantic warrior past of 'kilts, misty glens, haunting Celtic music (and) oppressive English soldiers' which in more contemporary terms could be readily redefined in relation to the oppressive English political credo of Thatcherism (Bicket 1999, p. 3). 


\section{Thatcherism, and the 'Scottish Myth'}

Anti-Thatcherite sentiment in Scotland can also be seen as at least partly invoked by her political style and displacing of a 'gentler' traditional one nation Toryism, supplanting this ostensibly more inclusive and 'benign' strand of conservatism with a more competitive (petit bourgeois) market fundamentalism and 'unforgiving', aspirational enterprise culture (Riddell 1985).

With respect to the impact of this shift on Scotland, superficially it might seem reasonable to observe that the values of self-reliance, hard work and opportunity associated with Thatcherism might resonate well with aspects of the Scottish Myth that emphasize 'getting on'. For example, the Kailyard icon of the aspirational and socially mobile 'lad o' pairts'; usually a rural youth of humble origins and academic promise who rises socially and economically under the guidance of a benevolent minister or teacher ('dominie') (McCrone 1992).

On this point, gender issues aside, it could be argued that Nicola Sturgeon's persona and back story resonates to a significant extent with this Kailyard myth, as a person of evident talent from a working class background, regarded by many as being particularly honest and diligent, whose rise to prominence appeared to be supported by an experienced mentor, Alex Salmond. The emergence of the Salmond affair and the dramatic breaking of this relationship, while also revealing previously muted fissures and factionalism with the SNP, was perhaps more shocking given the shattering of the assumed friendship and solidarity between these two major figures. Nonetheless, it can be argued that it was the Scottish public's continued belief in Sturgeon's personal character that saw her weather this turbulent period, as vigorous opposition efforts to exploit this affair failed to significantly tarnish her public image in the run up to the 2021 election.

Returning to the imagery of the 'lad o' pairts' itself, this might superficially be regarded as a counterpart to the heroes of the US 'Horatio Alger Myth', as an aspirational cultural figure informing the 'rags to riches' iconography of the American Dream and thus ostensibly reconcilable with the neoliberal zeitgeist. However, the Kailyard imagining of self-reliant mobility is more equivocal, tempered by a much greater sense of asceticism, empathy and humility, reflecting the strong influence of its presbyterian roots and, perhaps, even a sprinkling of Scandinavia's Janteloven self-deprecation and communitarianism given these regions' longstanding historical ties (Trotter 2018).

While there may always have been more support for Thatcherite values in some quarters than many Scots would care to admit, particularly in the rural north east and border regions, and while the Thatcherite policy of selling council houses was widely popular, nonetheless it seems clear that the harsh self-interest, hyper-individualism and brash competitiveness of this credo remains anathema to much of Scotland (Gammon 2013). This is particularly the case with respect to post-industrial areas of the central belt, as an area that has also been associated with another key Scottish identity trope, Clydesideism, which aside from its hegemonic masculine aspects, also emphasised collectivism and socialism as key features of identity for a large swathe of Scots (Bicket 1999). The latter region, where heavy engineering, manufacturing, shipbuilding and steel were once major 
sources of employment, was particularly ravaged by the Thatcherite economic and industrial policies of the 1980s, as well as the erosion of the welfare state that once cushioned lives rendered precarious by rapid industrial decline (Devine and Finlay 1996).

As Devine has noted, pre-Thatcher, Britain's moral tone and espoused sense of fair play and social justice, symbolized by the post war welfare state, was a set of values that could reasonably co-exist with Scots' self image (Devine and Finlay 1996; Smout 1994). Such binding features of Britishness in Scotland, however, could also be seen to whither with the Thatcherite ascendancy and the austerity politics that it more recently spawned.

If, as above, Scotland has been moving away from England politically and, to some extent, culturally it may be suggested that this was also a response to reciprocal changes in English identity. Thus, Thatcherism, while reshaping the political landscape, also offered a different symbolic vision of England. Crucially, the rise of right-wing English nationalism, that appeared to grow in tandem with Thatcherism, can be seen to have deepened a mutual 'othering' of the Scots amongst significant segment of the English populace. As well as charting an increase in English in relation to British identity. Jeffery et al (2014) pointed towards an element of antiScottish sentiment amongst those identifying as predominantly English, a trend that became increasingly apparent with the Scottish referendum. Thus, as noted at the outset, both Scottish and English national identity have become more salient and oppositional in recent decades (Henderson et al. 2016).

\section{Neoliberal angst, atomisation, community and collective action}

As argued above, the Anglo-Scottish political and cultural divide has been widening to a point where an easy return to something like the relatively stable post-war relationship seems unlikely. As noted, however, in coming to an understanding of these processes it is insufficient simply to refer to the more overt aspects of politics and identity outlined above. Rather, the political and cultural fracturing of the UK is best understood within the context of deeper underlying factors driving instability and division more widely. Relating this to Eatwell and Goodwin's argument regarding the intertwining of economic and cultural factors in exacerbating political turbulence, with greater public demonstration of the latter, this would fit with the notion that Scottish politics has been stimulated by economic insecurities but played out in nationalist terms (2018). However, it is argued here that it is economic insecurity and inequality that are the underlying drivers of a more emotionally charged politics that finds its expression in cultural enmities and nationalist sentiment. This is a crucial point, explored in more detail below, as it connects to a set of arguments associated with the more fundamental effects of neoliberalism that, as argued elsewhere, have unleashed tendencies towards public restiveness, cultural defence and 'othering' in response to the longer-term emotional effects of endemic precarity, competition, insecurity and social estrangement (Bellah et al. 1985; Bone 2010; Standing 2011). 


\section{Biosocial correlates of collective identification under stress}

As proposed at the outset, while many of the factors driving our more divisive politics are well observed, some of the deeper underlying roots of these processes can be more clearly understood with reference to contemporary biosocial theory (Bone 2010, 2016). The latter contends that feelings of powerlessness, disillusionment and isolation, together with conditions of unpredictability, insecurity, and dissonance in terms of values, expectations and experience, together with overwhelming demands and complexity, can generate chronic states of negative emotional arousal; principally anger and fear (Arnsten, 2009). Relating the latter directly to the aforementioned conditions imposed by neoliberalism-insecure work and housing, the pressures and demands placed on the contemporary workforce, the information overload of living in a digital world, and the status anxieties experienced within highly unequal, competitive, aspirational societies-coalesce to impose an unwieldy cognitive and emotional burden on contemporary individuals (Bone 2005, 2006, 2010, 2014, 2016). A key factor affecting our response to these conditions arises from the fact that our working memory - centrally involving the pre-frontal cortex [pfc]) and associated with higher order thought, calculation and reflection-has a limited capacity in terms of readily accommodating to multiple demands, dissonances and unpredictable experiences (McElree 2001). In effect, the very fact of living in modern societies, and particularly within populous urban environments, of itself taxes our capacity to comfortably engage with and manage the myriad experiences that we are exposed to (Lederbogen et al 2011; Bone 2010, 2016).

\section{The social map}

In adapting to the world, via our extensive socialisation we build an internal template or 'map' of what our world is like-and to an extent how we think it should be-by identifying, classifying, internalising and habituating to regularly encountered objects, experiences, situations, identities, values and social norms, committing these to long term and procedural memory (Bone 2005, 2006, 2010, 2016). This internalised model frames subsequent experiences, informs our expectations and action, while enabling us to readily identify and handle familiar and routinely encountered situations at a low level of consciousness, largely ignore the inconsequential, critically freeing up the 'executive' to focus on novel situations and those previously deemed especially significant and, thus, that require conscious attention (McElree 2001; Bone 2010, 2016). Where our social circumstances seem relatively manageable, stable and predictable, and where our place in the world in relation to others also seems fairly secure and relatively positive, we can more easily rely on well-practiced routines and, hence, more readily cope with living in complex societies. On this latter point, as argued more extensively elsewhere, we evidently do not thrive in conditions of stultifying routine either, but most appear best served by having firm foundations that are regularly enlivened by a modicum of relatively 
predicable emotional stimulation. Such conditions render living meaningful while conferring a 'balanced' state of emotional arousal (Bone 2010, 2016).

The stabilising effects of the post war settlement might be more clearly understood within this context, in terms of conferring a modicum of these 'social goods' for many; less inequality, greater job security and welfare and relatively affordable and secure housing, together with 'comfortable' and relatively predictable stimulation through leisure and entertainment to render life enjoyable.

By contrast, where the social fabric we are presented with regularly and significantly fails to met with our internalised expectations, while presenting us with greater demands, complexity and unpredictability than we can readily accommodate to, we experience an unnerving sense of dissonance, potential threat and lack of control, triggering the brain's 'fear and anger system' (principally associated with the amygdala and closely related structures) and the readying of the central nervous system for action (LeDoux 1998; Bone 2010). Such conditions also narrow our focus of attention towards the immediate and emotive, while extended sensitisation of the amygdala has the capacity to impact on the functioning and neural connections within the pfc, the consequences of which can impair ability for rational, measured thought in favour of more emotionally driven responses and thinking (Fredrickson and Branigan 2005; Arnsten 2009). This is consistent with the more angry and unstable politics noted above and, indeed, other forms of emotionally charged conduct that has become more prevalent in the neoliberal era, as was the case with other periods of socio-economic turbulence in the past (Arnsten 2009; Mishra 2017; Bone 2010).

Specifically, it is argued that neoliberalism can be seen to have unleashed destabilizing forces with deep implications for our cognitive and emotional constitution, stimulating in response a growing latent emotionally charged insurgency amongst those who have lost out in frenetic, competitive and alienating societies, who have a tendency to seek outlet and vehicles for restitution, collective mobilization and security in a variety of forms that may span the ideological, political, and even religious spectrum (Zaitchik, 2016). This resonates with consistently observed sociological phenomena, for example where peoples in transition or experiencing other forms of precarity have tended to gather together, embrace and emphasise their shared heritage, culture and often religion as a psychological bulwark against the sort of feelings of dislocation, isolation, insecurity and injustice described above (Bellah et al. 1985; Bruce 2000; Gilchrist et al. 2010).

A shared identity, whether based on residence, religion, common outlook or even an overlapping experience of oppression, appears to offer a haven- $\mathrm{a}$ psychological space where an individual feels secure and can 'be themselves' without fear of ridicule, misunderstanding or hostility. It is a way of demarcating 'us' and 'them', and, unfortunately, in our increasing complex and diverse society, this can be a source of division and discrimination, as well as a means of managing uncertainty (Gilchrist et al. 2010).

In line with the above, it is argued here that almost any form of collective identity and action that readily presents itself as a vehicle for communal affiliation, to assuage, make sense of and challenge popular discontent will be embraced by 
stressed and disenchanted peoples, possibly reflecting a growing need for what the anthropologist Victor Turner labelled 'communitas' (1974); a feeling of shared experience, feeling and destiny that is largely lacking in everyday life in contemporary societies (Bellah et al. 1985; Bone 2006; Fredrickson and Branigan 2005).

For contemporary citizens, as bearers of complex multidimensional and overlapping identity markers, the aspects of identity, national or otherwise, that are expressed and come to the fore may also be highly contingent on immediate circumstances (Maffessoli 1996). Thus, as argued above, events such as the Independence Referendum and Brexit will tend to 'key' national sentiments, particularly in inherently uncertain, shifting and atomized environments. This is also more likely where there are few other readily accessible alternative collective identifications, with the decline of class consciousness, trade unions and community associations (Putnam 2000).

Such responses to neoliberal globalisation have evidently emerged from grassroots movements, with some associated with socially positive and progressive agendas, examples being Occupy, Black Lives Matter, support for the NHS during the pandemic, and a variety of other pro-social, democratic and environmental movements. Some spontaneous collectives have also emerged with no specific social, political or ideological complexion other than opposition to the status quo, for example, the protests associated with France's Gilet Jaunes (Yellow Vests) (Reuters, 6 December 2018). Even more extreme examples of the desire for meaning, identity and belonging can be observed in the growth of US Trump supporting militia groups and in the rise of conspiracy theories in response to the pandemic, including those promulgated by the strange QAnon adherents as a movement that emerged in the US and which has support in the UK (Baker 2020). It is also notable that people experiencing a lack of control over their lives are more susceptible to embracing such collectives.

\section{Top down mobilization}

In addition to grassroots movements, however, the febrile conditions generated by neoliberalism may also be seen to have provided fertile ground for top down mobilization or, indeed, exploitation of popular unease. This is also, in some respects, in keeping with Kornhauser's mid twentieth century work, identifying the tendency for highly individuated and disaffected populations to become more susceptible to political manipulation (1959).

At least to some extent the resurgence of Scottish, and indeed English, national sentiments can be understood with reference to the above, in a process that is in many respects broadly akin to the political mobilization and state formation identified by Gellner, Anderson and so on being played out against the background of destabilised lives and identities (Gellner 1983; Anderson 1983). Specifically, there is a considerable body of evidence supporting the notion that identities are strengthened by emotional arousal and repeated 'keying' of prominent cultural themes, and most particularly where these are already broadly accepted or are consistent with pre-existing beliefs and identifications (LeDoux 1998; Bone 2006, 2010). Thus, 
repeated 'keying' of pre-existing nationalist themes by political figures and their supporters in the mass media-and particularly those skilled in rhetorical techniques that appeal to hope, fear, resentment and disenchantment-is evidently greatly facilitated where this is directed towards an already emotionally sensitised populace (Goffman 1974; Bone 2006; Duffy et al 2021). Social media has also evidently made a significant contribution to this scenario of late, including its capacity to produce extreme collectives such as QAnon. On the one hand, as above, this has taken the form of genuine grass-roots engagement being facilitated via online platforms. Equally, however, the power of the mainstream media to set the discursive agenda may often entail that susceptible populations will actively reinforce as much as they resist hegemonic discourses proffered by political, media and, indeed, business interests via 'viral' proliferation of emotionally salient content online on an unprecedented scale (Stieglitz and Dang-Xuan 2013).

...media-savvy performance of politics appears to become more important than the political process (Grande 2000). Accordingly, politics becomes simplified and dumped down to a few slogans apparently comprehensible to the broad public at large (Wodak et al. 2013, p. xvii).

Turning specifically to the issues at hand, popular discontent with the perceived inequities and travails of life under neoliberalism in Scotland could be made sense of and opposed via the convenient and readily accessible, pre-existing values and collective identifications associated with the Scottish Myth, while there can be seen to be little difficulty in reviving and reframing sentiments associated with the latter to fit with the broadly social democratic vision offered by the SNP. The fact that Scotland's brand of nationalism has also offered an outlet and vehicle for popular disenchantment, as well as a potential 'exit' by means of an existing national institutional framework, potentially made this direction of travel highly likely once the erstwhile defenders of UK social democracy, Labour, had been irredeemably tarnished in Scotland. Moreover, this scenario of Scotland's estrangement further intensified via the Brexit process, as populist English politicians increasingly employed English nationalism as a thinly veiled vehicle for further advancing a largely discredited neoliberal project. Thus, as in the US, popular discontent in England has been more successfully redirected from the economic sphere, and the business and financial elites who have benefited from the dismantling of the post-war settlement, by appeals to social conservatism and ethno-nationalism, pointing to left liberal 'elites' and immigrants as the source of contemporary malaise. Antipathy towards Scotland in general and the SNP in particular has also been bound up with this process, reinforcing the nationalist cause north of the border.

\section{Directions of travel: a 'new normal' or business as usual}

Of the many paradoxes and ironies afflicting contemporary politics in the UK and elsewhere, perhaps the most perplexing is the way in which the neoliberal project, ostensibly derailed by the credit crisis of 2007/8, has seemed to be surreptitiously revived via nationalist discourses. Thus, in the UK, the US, and other nations across 
Europe, right wing populist politicians have successfully exploited discontents and enmities generated by neoliberalism, only to further advance that agenda via the nationalist mobilization of both its supporters and, it could be argued, its victims (Cozzolino 2018). A key question arises as to how likely that will be in a potentially economically destabilised post-pandemic scenario, and what this might mean for the political situation in the UK.

In the aftermath of the credit crisis numerous pundits proposed that the era of deregulated free markets had come to an end, as many of its asserted advantages, of assumed meritocracy, stability and economic efficiency, that had sustained the legitimacy of that model in the face of growing social problems, had begun to ring increasingly hollow. The activities of finance had exposed the long running mantra of self-regulating markets to be fatally flawed, while revealing that many of those who had made great gains during the neoliberal era had not done so by creating wealth, at least in the way in which this was normally understood. Rather, it appeared that much of the wealth generated by those at the top had been acquired via gaming the system; by financiers engaging in non-productive chicanery, by speculators gambling in a variety of commodity and asset markets (including property), and by corporate managers gaining control over their remuneration at the expense of their companies and, crucially, ordinary workers (Krugman 2008; Tett 2009; Walby 2013; Bone 2016). It was also clear that much of this 'wealth' had evaporated in the crash, only to be restored by government bailouts in its aftermath (Korten 2008; Bone 2016). Moreover, the latter contrasted starkly with the austerity imposed on publics, ostensibly as a means of restoring government finances, but which also afforded cover for a further shrinking of state provision.

As above, what was notable after the crisis was the way in which its causes were redefined and, crucially, the neoliberal project was reframed. In the first instance, the crisis generated by the under-regulated banks was rewritten as a narrative around state intervention and regulation of markets and, also, critically in the UK, as an economic crisis generated by Labour government overspending (Pettinger 2019).

In terms of the argument at hand, as we know, those who have lost out have been championed by 'disruptive', populist politicians like Trump purporting to offer hope and a positive identity framed in strident nationalist terms, as advocates of 'the people'. A list of adversaries have been presented, comprised of immigrants (charged with competing for jobs and diminishing services), supra-national institutions, 'undeserving' welfare recipients and, not least, alleged cultural and liberal elites whose pro-government, liberal and cosmopolitan sensibilities operate against the sentiments and moral compass of the silent majority. A notable omission from this range of 'enemies', however, is the sector of the business elite who continue to prosper from current economic arrangements and who are most dependent on a return to 'business as usual'. Thus, there has been considerable diversion from the actual nature of the political and economic agenda being advocated. For example, in the US, Trump's much promulgated tax cuts, despite the trumpeting of minor concessions to average earners, appeared consistent with the agenda of supporting the wealthy and corporations as opposed to his working class constituency (New Compass, 7 January 2018). 
This scenario of the right and wealthy presenting themselves as advocates of the working class has evidently been mirrored in the UK, via UKIP and its successor Brexit Party, during Nigel Farage's tenure, as well as the rhetoric employed by the Brexiteer wing of the Conservative Party. Thus, discussion of rolling back the state, plans for further deregulation in a variety of areas and tax cuts, particularly for 'wealth creators', are downplayed in favour of 'anti-establishment', nativist, jingoistic and collectivist rhetoric (Davies 2020).

Overall, as noted at the outset, this strategy that has not only been successful in attracting the traditional amalgam of petit bourgeois and wealthy voters to the Conservative fold, but also a significant tranche of a beleaguered working class and is central to a growing culture war on both sides of the Atlantic, as indicated above, bound together with strident nationalist identifications (Zaitchick 2016). In this sense, the rise of Scottish Nationalism might not be viewed in isolation but as one, albeit more benign, feature of a wider phenomenon that is growing in democratic societies as neoliberalism has eroded the social fabric. What is important for the argument here is that one expression of this phenomenon in the UK is its contribution to the growing divisions between Scotland and England.

It now seems clear that the arrival of COVID 19 has further amplified these divisions, as Scotland's First Minister, Nicola Sturgeon, has appeared to take a significantly more assertive approach to handling the pandemic, and a more cautious approach to the relaxation of measures aimed at its containment.

The impression created has been that Scotland's government, as with Wales and Northern Ireland, has appeared to place more weight on public health than private wealth than the UK government. In Scotland's case this stance can be seen to be in keeping with the key tropes of Scotland's national self-identification, of reason, egalitarianism, collectivism, empathy and solidarity, regardless of the actual prevalence of these characteristics. This variation in approach has reinforced perceptions of Scotland and England as separate communities and jurisdictions, pointing towards the further widening of the direction of travel between the nations (Smith 2021). The outcome of the 2021 Scottish Election seems to have underlined the continued support for Sturgeon and her approach to the pandemic as well as this sense of Scottish separatism. This is despite the UK government and Scottish Conservative politicians' efforts to highlight the success of the vaccination programme and the furloughing of workers as benefits of the union while attempting, as noted, to dent Sturgeon's public image.

\section{Conclusions}

The above factors, taken together, attempt to engage with at least some of the complexities and paradoxes surrounding the UK's current political, constitutional and nationalist turbulence in an era of increasing uncertainty. In effect, amid the throes of a global pandemic and a potentially more serious economic crisis than 2007/8, the UK is also confronting its own 'culture wars', with whichever faction wins out shaping the direction of a post-pandemic and, indeed, post-Brexit economy and society. As such, the stakes cannot be higher. In fundamental respects, as alluded to 
above, there are clear parallels with the increasingly angry divide that has emerged in the US and some other nations in recent decades; fuelled by perceived inequalities, insecurities, divisions, resentments and discontents regarding the direction of mainstream politics and society, that have simultaneously exacerbated ethnic and other social divisions. Underlying this is a ferment of growing negative emotional arousal being experienced by those disaffected by current socio-economic and political arrangements. As noted, the consequences of the latter have often been multidimensional and contradictory, with those feeling disenfranchised and opposed to the status quo often fracturing in seemingly diametrically oppositional directions, cleaving to the most resonant collective vehicle through which to express their discontents (Langham 2011). In the UK, however, as argued, to a significant extent the factions that are forming are to some extent coalescing around sub-national lines.

With respect to Scotland and its representative governing party, its rise may be understood with respect to the readily available national identifiers, increasingly electable political movement, institutional supports as well as, not least, the availability of a complementary national discourse, the 'Scottish myth', to inform a 'reasonable' progressive anti-neoliberal national identity around which discontent and 'insurgency' might be framed. The simultaneous dominance of an English neoliberal establishment, and a right-wing 'xenophobic' English nationalism, can be seen to have offered a further oppositional bulwark to the construction of this revived Scottish project. These factors go some way to explaining why Scottishness, arguably a residual sense of identity for many modern northern Britons until relatively recently, has been strengthened by recent events to a degree that has significantly transcended the circumstances (the referendum) by which it was invoked, contributing to the phenomenal rise of the SNP as a significant force in UK politics. It might well be argued that the tropes of Scottish identity that have come to the foreof empathy, solidarity, social democracy, social justice and so on-may clearly be regarded as being benign or even progressive. However, in a sense these progressive movements may be seen to have sprung from the same wellspring that has also spawned UKIP, the Brexit Party and Brexiteer Conservatism, as well as a variety of right-wing and other 'extremist' and populist movements across Europe and beyond, and not least the divisive populism that continues in the US despite Donald Trump's defeat in the 2020 election. Overall, it is argued here, that all of these developments to greater or lesser extent are symptoms of socio-political processes that have their roots in the distress generated by increasingly anomic, unpredictable, unjust and disorientating societies and, as such, there is a deeper biopsychosocial relationship to be understood that underlies much contemporary political and constitutional cut and thrust.

Finally, polling from YouGov during the pandemic has tended to indicate that there may be growing cleavages amongst the UK populace in terms of what should happen in a post-pandemic society, with significant reticence regarding a return to business as usual (YouGov cited in New Economic Foundation 2020). It may well be the case that the pause for thought presented by lockdown, and furloughing for some, has led people to reflect more closely on the role that work and consumerism plays in their lives, as well as the nature of a society where the latter are overwhelmingly predominant. However, giving UK governments' longstanding stance 
in this regard, as well as divisions amongst the English regions and segments of the population over work and economy, it would seem unlikely that significant deviation from the prior status quo will be in prospect. The Johnson government's evident desire to get back to 'normal' and the suggestion of further deregulation post-Brexit would tend to support this perspective (Dearden 2020). By contrast, given the prevalence of anti-neoliberal sentiment in Scotland, those wishing for a change of direction north of the border retain a ready-made vehicle through which to channel this type of ambition in the form of a potential second referendum.

\section{References}

Arnsten, A.F.T. 2009. Stress signalling pathways that impair prefrontal cortex structure and function. Nature Reviews Neuroscience 10 (6): 410-422. https://doi.org/10.1038/nrn2648.

Anderson, B. 1983. Imagined communities: Reflections on the origin and spread of nationalism. London: Verso.

Baier, W. 2016. Europe on the precipice: The crisis of the neoliberal order and the ascent of right-wing populism. New Labor Forum. 25 (3): 48-55.

Baker, S.A. 2020.Tackling misinformation and disinformation in the context of COVID-19. Cabinet Office C19 Seminar Series.

Bellah, R.N., R. Madsen, W.M. Sullivan, A. Swidler, \& S.M. Tipton. 1985. Habits of the heart: Individualism and commitment in american life. Berkeley: University of California Press.

Bicket, D. 1999. Fictional Scotland. Journal of Communication Inquiry 23 (1): 3-19.

Bone, J. 2005. The social map and the problem of order: A re-evaluation of 'Homo Sociologicus'. Theory and Science. 6 (1).

Bone, J. 2006. The social map: Cohesion, conflict and national identity. Nationalism and Ethnic Politics 12 (3-4): 347-372. https://doi.org/10.1080/13537110600882510.

Bone, J. D. 2010. Irrational capitalism: The social map, neoliberalism and the demodernization of the West. Critical Sociology 36 (5): 717-740. https://doi.org/10.1177/0896920510371387.

Bone, J. 2014. Neoliberal nomads: Housing insecurity and the revival of private renting in the UK. Sociological Research Online 19 (4): 1-14. https://doi.org/10.5153/sro.3491.

Bone, J. 2016. The nature of structure: a biosocial approach. The Sociological Review Monographs 64 (1): 238-255. https://doi.org/10.1002/2059-7932.12023.

Bruce, S. 2000. Religion, cultural defence, and transition. In Religion in modern times: An interpretive anthology, ed. L. Woodhead and P. Heelas. Oxford: Wiley.

Byrne, C., N. Randall, and K. Theakston. 2020. Disjunctive prime ministerial leadership: From baldwin to Brexit. London: Palgrave.

Colley, L. 1992. Britishness and otherness, an argument. Journal of British Studies. 31: 309-329.

Connor, W. 1994. Ethnonationalism: The quest for understanding. Princeton: Princeton University Press.

Cox, L. 2021. Nationalism and populism in the age of globalization, in nationalism. Singapore: Palgrave Macmillan.

Cozzolino, A. 2018. Trumpism as nationalist neoliberalism, a critical enquiry into Donald Trump's political economy. Interdisciplinary Political Studies. 4 (1): 47-73.

Davidson, N. 2014. A Scottish watershed. New Left Review 89 (2): 5-26.

Dearden, N. 2020. Is shifting to US-style deregulation the inevitable consequence of Brexit? Soundings: A Journal of Politics and Culture. 75: 82-94.

Davidson, N. 2008. Nationalism and neoliberalism. Variant 32.

Davidson, N., P. McCafferty, and D. Miller. 2010. Neoliberal Scotland: Class and society in a stateless nation. Newcastle: Cambridge Scholars.

Davies, W. 2020. The Great British Battle: How the fight against coronavirus spread a new nationalism. The Guardian. $16^{\text {th }}$ May.

Dorling, D. 2019. 'Brexit: A fairer future?' Address for British Science Festival. September.

Duffy, B., K. Hewlett, G. Murkin. et al. 2021. Culture wars in the UK: division and connection. King's College, Ipsos. 
Eatwell, R., and Goodwin, M. 2018. National populism: The revolt against liberal democracy, Harmondsworth, Pelican.

Gallas, A. 2015. The thatcherite offensive: A neo-poulantzasian analysis. Leiden:Brill.

Gilchrist. A., M. Bowles, and M. Wetherell. 2010. Identities and social action: Connecting communities for a change. Identities: Community Development Foundation.

Hassan. G. 2012. What are modern Scotland's three defining stories? Scottish Review. 4th December.

Devine, T., and R. Finlay, eds. 1996. Scotland in the twentieth century. Edinburgh: Edinburgh University Press.

Edgerton, D. 2019. The rise and fall of the British nation: A twentieth-century history. Harmondsworth: Penguin.

Elkins, C. 2005. Britain's gulag: The brutal end of empire in kenya. London: Jonathan Cape.

Fieldhouse, E., J. Green, G. Evans, et al. 2020. Electoral Shocks in a Volatile World. Oxford: Oxford University Press.

Fredrickson, B., and C. Branigan. 2005. Positive emotions broaden the scope of attention and thoughtaction repertoires. Cognition and Emotion. 19: 313-332.

Gammon, E. 2013. The Psycho- and sociogenesis of neoliberalism. Critical Sociology. 39 (4): 511-528.

Gellner, E. 1983. Nations and nationalism. Ithaca: Cornell University Press.

Goffman, E. 1974. Frame analysis. Harmondsworth: Penguin.

Goodwin, M.J., and O. Heath. 2016. The 2016 referendum, Brexit and the left behind: An aggregate-level analysis of the result. The Political Quarterly. 87 (3): 323-332.

Gusterson, H. 2017. From Brexit to trump: Anthropology and the rise of nationalist populism. American Ethnologist. 44 (2): 209-214.

Harvey, D. 2007. Neoliberalism as creative destruction. The Annals of the American Academy of Political and Social Science. 610 (1): 21-44.

Henderson, A., C. Jeffery, et al. 2016. England, englishness and Brexit. The Political Quarterly 87 (2): 187-199.

Hobolt, S. 2016. The Brexit vote: A divided nation, a divided continent. Journal of European Public Policy 23 (9): 1259-1277.

Hobsbawm, E., and T. Ranger. 1983. The invention of tradition. Cambridge: Cambridge University Press.

Jeffery, C., R.W. Jones, A. Henderson, R. Scully, and G. Lodge. 2014. Taking England seriously: The new English politics. The Future of England Survey.

Keating, M. 2011. Scotland and independence. Montréal: The Federal Idea.

Keating, M. 2007. Scottish social democracy: Progressive ideas for public policy. Brussels: Peter Lang.

Kornhauser, W. 1959. The politics of mass society. Glencoe: Free Press.

Korten, D. 2008. Agenda for a new economy. San Francisco: Berrett-Koehler.

Krugman, P. 2008. The return of depression economics and the crisis of 2008. New York: Norton.

Langham, L. 2011. Cycles of contention: The rise and fall of the tea party. Critical Sociology 1 (26).

Lederbogen, F., P. Kirsch, L. Haddad, et al. 2011. City living and urban upbringing affect neural social stress processing in humans. Nature 474: 498-501.

LeDoux, J. 1998. The emotional brain: The mysterious underpinnings of emotional life. New York: Simon and Schuster.

Maffesoli, M. 1996. The time of the tribes: The decline of individualism in mass society. London: Sage.

McCrone, D. 1992. Understanding Scotland: The sociology of a stateless nation. London: Routledge.

McCrone, D. 2002. Who do you say you are? Making sense of national identities in modern Britain. Ethnicities 2 (3): 301-320.

McElree, B. 2001. Working memory and focal attention. Memory and Cognition. 27 (3): 817-835.

McGarvey, N., and F. Stewart. 2016. European, not British? Scottish nationalism and the EU referendum. In The future of the UK, between internal and external division, edited by M Guderjan. Berlin: Westkreuz-drucherei Adrens.

Mishra, P. 2017. The age of anger: A history of the present. London: Allen Lane.

New Economics Foundation. 2020. YouGov Poll Results, June. https:/neweconomics.org/uploads/files/ YouGovresults_BBB_June2020.pdf

Paterson, L. 2014. The paradox of Scottish political culture. Scottish Affairs. 23 (3): 291-308.

Paul, D. 2020. The "civic" road to secession: Political ideology as an ethnic boundary marker in contemporary Scotland. Nationalism and Ethnic Politics 26 (2): 167-182.

Pettinger, T. 2019. Can Labour be blamed for the economic crisis? Economicshelp. 12th June. https:// www.economicshelp.org/blog/14006/economics/can-labour-be-blamed-for-the-economic-crisis/. 
Putnam, R. 2000. Bowling alone: The collapse and revival of American community. New York: Simon \& Schuster.

Riddell, P. 1985. The thatcher government. Oxford: Martin Robertson.

Scholes, A., and J. Curtice. 2020. The changing role of identity and values in Scotland's politics. Scottish Social Attitudes.

Smith, J. 2021. COVID-19, Brexit and the United Kingdom-A year of uncertainty. The round Table 110 (1): $62-75$.

Smout, T.C. 1994. Perspectives on the Scottish identity. Scottish Affairs. 6: 101-113.

Standing, G. 2011. The precariat. London: Bloomsbury.

Stieglitz, S., and Dang-Xuan, Linh. 2013. Social media and political communication: A social media analytics framework. Social Network Analysis and Mining. 3 (4): 1277-1291.

Tett, G. 2009. Fool's gold: How unrestrained greed corrupted a dream shattered global markets and caused a catastrophe. London: Little Brown.

Trotter, S. 2018. Breaking the law of Jante. Myth and Nation 23: 1-18.

Turner, V. 1974. Dramas, fields, and metaphors: Symbolic action in human society. Cornell University Press.

Wacquant, L. 2009. Punishing the poor: The neoliberal government of social insecurity. Durham/London: Duke University Press.

Walby, S. 2013. Finance versus democracy? Theorizing finance in society. Work Employment Society. 27 (3): 489-507.

Wodak, R., M. Khosravinik, and B. Mral, eds. 2013. Right-wing populism in Europe: Politics and discourse. Bloomsbury Academics.

Zaitchick, A. 2016. The gilded rage: A wild ride through Donald Trump's America. New York: Hot Books.

Publisher's Note Springer Nature remains neutral with regard to jurisdictional claims in published maps and institutional affiliations. 